\title{
Transtorno do processamento auditivo (central) em indivíduos com e sem dislexia***
}

\author{
(Central) auditory processing disorders in individuals with and \\ without dyslexia
}

\author{
Mariana Buncana Simões* \\ Eliane Schochat**
}

\begin{abstract}
*Fonoaudióloga Clínica. Mestre em Ciências da Reabilitação pela Faculdade de Medicina da Universidade de São Paulo (FMUSP). Endereço para correspondência: R. Bourbon, 84 São Paulo - SP - CEP 04663-160 (simoesmari@hotmail.com)

**Fonoaudióloga. Livre-Docente do Curso de Fonoaudiologia da FMUSP. Professor Associado do Curso de Fonoaudiologia da USP.

***Trabalho Realizado no Laboratório de Investigação Fonoaudiológica em Processamento Auditivo (Central) do Setor de Audiologia do Centro de Docência e Pesquisa em Fisioterapia, Fonoaudiologia e Terapia Ocupacional da FMUSP.
\end{abstract}

Artigo Original de Pesquisa

Artigo Submetido a Avaliação por Pares

Conflito de Interesse: não

\begin{abstract}
Background: comparison of (central) auditory processing disorders in children with and without dyslexia. Aim: to compare the (central) auditory processing disorders in Brazilian children with and without dyslexia using speech in noise, dichotic digits and pattern of frequency tests. Method: forty-five children with ages ranging between 7:0 and 12:11 years were assessed; twenty children composed the dyslexic group and twenty composed the (Central) auditory processing disorder group. The tests used involved closing aural, auditory figure-ground and temporal ordering abilities. Results: individuals of the (Central) auditory processing disorder group presented a higher alteration probability in the speech in noise and dichotic digits tests than those from the dyslexic group. Conclusion: subjects from the dyslexic group presented different patterns of (central) auditory processing disorder, with greater alteration in the tests that evaluate the temporal processing when compared to the tests that evaluate other auditory abilities. Key Words: Auditory Perception; Dyslexia; Child.
\end{abstract}

\section{Resumo}

Tema: comparação do transtorno do processamento auditivo (central) em indivíduos com e sem dislexia. Objetivo: comparar o transtorno do processamento auditivo (central) em crianças brasileiras com e sem dislexia, por meio dos testes fala com ruído, dicótico de dígitos e padrão de freqüência. Método: foram avaliadas 40 crianças de 7:0 a 12:11 anos, sendo 20 pertencentes ao grupo com dislexia e 20 pertencentes ao grupo TPA(C). Os testes aplicados envolveram habilidades de fechamento auditivo, figura-fundo para sons lingüísticos e ordenação temporal. Resultados: os indivíduos do grupo TPA (C) apresentaram maior probabilidade de alteração nos testes de fala com ruído e dicótico de dígitos do que os pertencentes ao grupo dislexia. Conclusão: os sujeitos do grupo dislexia apresentam padrões diferentes de transtorno de processamento auditivo (central), com alteração maior em testes que avaliam o processamento temporal do que em testes que avaliam outras habilidades auditivas.

Palavras-Chave: Percepção Auditiva; Dislexia; Criança. 


\section{Introduction}

The difficulty of learning reading and writing skills is present in disorders such as dyslexia, classified by the World Health Organization1 as a disorder manifested by specific difficulties in learning how to read, which are not caused by any other type of deficit related to intelligence, motivation, learning opportunities, or sensory acuity.

There is evidence suggesting that there is a relationship between learning disorders, such as dyslexia, and poor performance on several central auditory tests.2,3 Individuals with dyslexia have difficulty in distinguishing sounds and in terms of sensitivity to the melodic curve of the words (bass and treble, sequences, durations, intervals, etc.).4-6 This impairment makes it difficult for them to interpret sounds, which may cause learning difficulties and can be identified by the (central) auditory processing test. Central auditory processing disorder (CAPD) can be caused by abnormalities in the auditory nervous system. Such problems may be either lesionlike or functional abnormalities.

That is the reason why we decided to study the hearing processes in two different groups of patients. One group had dyslexia and CAPD (dyslexia group) and the other group had only CAPD (CAPD group). The objective of this study was to compare the central auditory processing test in the dyslexia and CAPD groups using the following tests: speech-in-noise, dichotic digit, and frequency pattern. We expected to find worse results in the assessment of temporal processing of individuals with dyslexia because learning disorders are typical of individuals with dyslexia.

\section{Method}

This study was approved by the Ethics Committee for Analysis of Research Projects (CAPPesq), Clinical Board, Hospital das Clínicas and School of Medicine, Universidade de São Paulo, under the research protocol no. 033/07.

\section{Patients}

Forty students aged between 7 and 12 years participated in this study. The present study was conducted at the Audiology Unit, Center of Teaching and Research in Physical Therapy, Speech Therapy and Occupational Therapy, School of Medicine, Universidade de São Paulo, Laboratory of Speech and Hearing Therapy Investigation of (Central) Auditory Processing.

The participants were all volunteers from the Laboratory of Speech and Hearing Therapy
Investigation of (Central) Auditory Processing of the Brazilian Dyslexia Association (ABD) and the Center for Interdisciplinary Neuropsychological Child Care (NANI) of Universidade Federal de São Paulo (UNIFESP).

Inclusion criteria were: absence of cognitive, psychological, neurological, and hearing impairment.7 We also defined some specific inclusion criteria for the selection of subjects in each group: dyslexia group - 20 individuals with dyslexia and CAPD caused by functional problems (they should have moderate to severe dyslexia and CAPD diagnosed by a multidisciplinary team); and CAPD group - 20 individuals with CAPD caused by functional problems (they should report problems related to reading and writing during the anamnesis carried out before the tests).

Equipment used for the hearing test was: Heine otoscope; sound booth; Grason-Stadler audiometer, model GSI-61;8 TDH-50 headphone set; lists of one- and three- syllable words; Grason-Stadler middle ear analyzer, model GSI-339.

For the behavioral tests of (central) auditory processing, we used a Panasonic CD-player coupled to the GSI-61; CDs Volume 1 and 2, with test recording edited by Pereira and Schochat,10 and a CD containing the frequency pattern test proposed by Musiek.11 The test administration complied with the guidelines set out in the Central Auditory Processing: Evaluation Manual, published by Pereira and Schochat.10 The following tests were administered: speech-in-noise, performed to check auditory closure ability; dichotic digit, to evaluate figure-ground perception of linguistic sounds; and frequency pattern, to assess temporal ordering. During the performance of the speech-in-noise test, the individuals would listen to a series of words (onesyllable words) in noisy conditions, and they should repeat the words. To perform the dichotic digit test,12 we presented 20 sequences of four digits and the individual should repeat them. During the frequency pattern test, 11 the individuals were instructed to name the sequence of tones heard (30 tone sequences). In order to achieve the objectives of this study, the likelihood of impairment for the dyslexia and CAPD groups were compared using the chi-square test for homogeneity.13 The level of significance was set at 0.05 (5\%). For values higher than 0.05, the null hypothesis (equality between groups) was considered; for values lower than 0.05 , the alternative hypothesis (statistically significant differences between groups) was considered. 


\section{Results}

The dyslexia and CAPD groups were compared regarding the distribution of the variable "result" in the speech-in-noise, dichotic digit, and pattern frequency tests. This variable was divided into two categories: normal and abnormal.

After using the chi-square test, we found that the likelihood of speech-in-noise and dichotic digit tests showing abnormal results is not the same in both groups
( $p=0.002$ ), being higher for the CAPD group. With regard to the frequency pattern test, the likelihood of abnormal results was the same in both groups $(p=1.000)$ (Table1).

Dyslexia and CAPD groups were compared regarding the distribution of the variable "result" on the speech-in-noise, dichotic digit, and pattern frequency tests (Figures 1 and 2). This variable has two categories: "abnormal" and "normal".

TABLE 1. P-values found in the comparison s between the groups on each test

\begin{tabular}{lr}
\hline \multicolumn{1}{c}{ Comparison } & $\mathrm{p}$ \\
\hline Speech-in-noise - Dyslexia vs. CAPD & 0.002 \\
Dichotic digit - Dyslexia vs. CAPD & 0.002 \\
Frequency pattern - Dyslexia vs. CAPD & 1 \\
\hline
\end{tabular}

P-value was considered statistically significant if $\mathrm{p}<0.05$.

FIGURE 1. Bar graph of the percentage of occurrence of result categories on the speech-in-noise, dichotic digit, and frequency pattern tests for the dyslexia group.

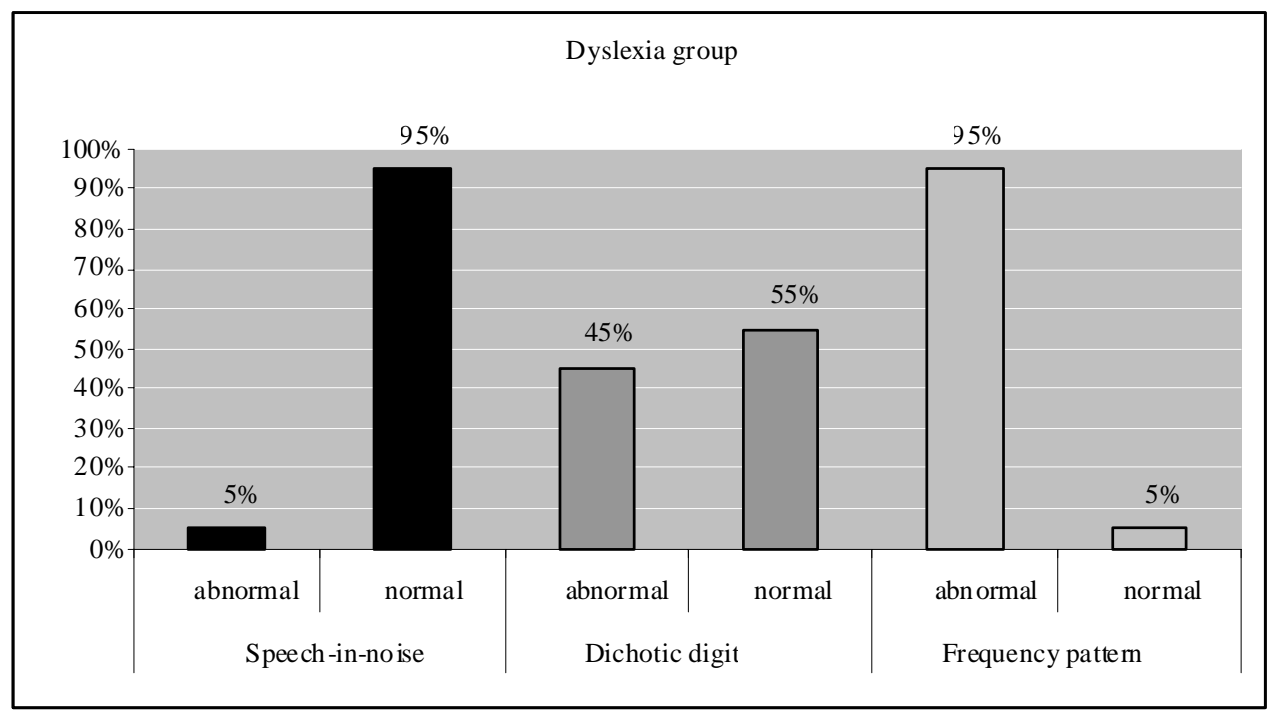


FIGURE 2. Bar graph of the percentage of occurrence of result categories on the speech-in-noise, dichotic digit, and frequency

pattern tests for the CAPD group

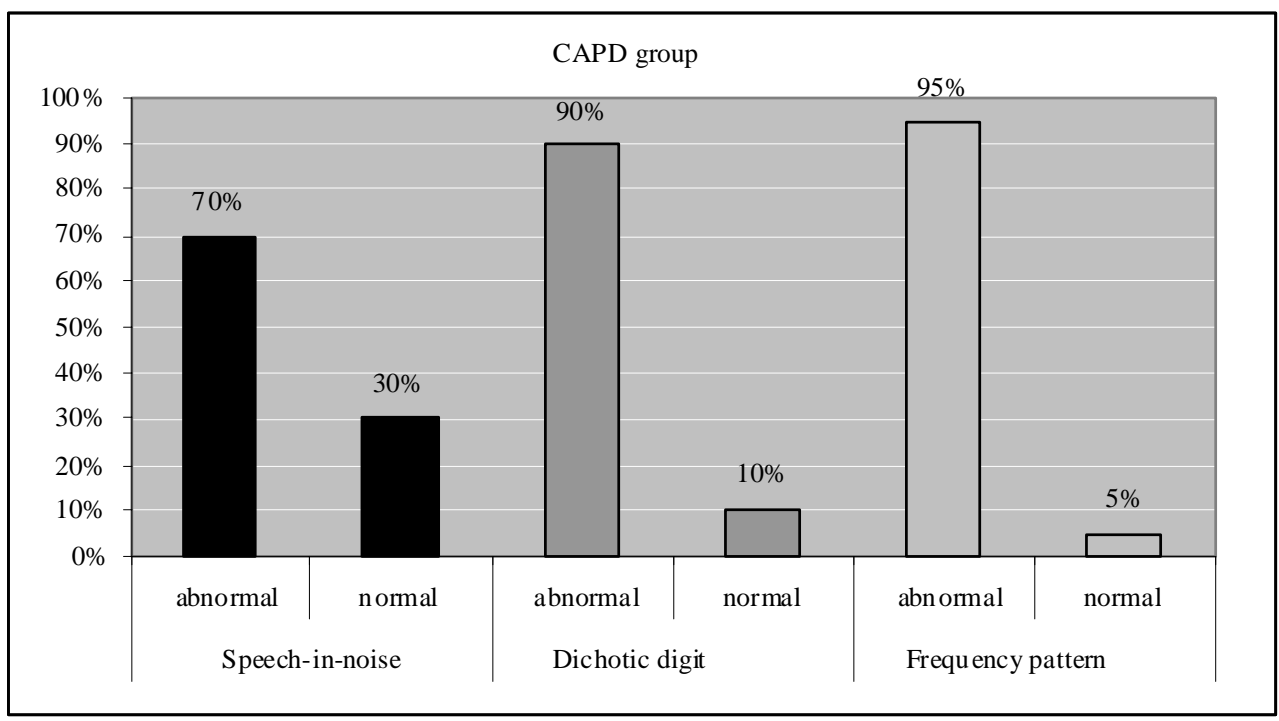

\section{Discussion}

For the analysis of CAPD assessment, the groups with CAPD and dyslexia were compared using the speech-in-noise, dichotic digit, and pattern frequency tests. We compared two types of results: normal or abnormal.

These three tests were chosen because they are easy to understand and administer, in addition to evaluating different hearing skills.

According to Katz and Ivey,14 the abnormalities we found suggest difficulties in the temporal ordering of sound events, impairment of short-term auditory memory, and difficulty to block competitive sounds, which is in agreement with the findings of the study by Talcott et al.,15 which identified an association between reading and auditory temporal processing. Our results also confirm the findings of several previous studies.

In the present study, we found a significant difference in the dyslexia group when evaluating different hearing skills. When comparing the CAPD and dyslexia groups, we found that individuals allocated to the first group have high rates of abnormal results on all tests, with impairment in all auditory skills tested. Most of the individuals belonging to the dyslexia group showed abnormal results only on the test that evaluates temporal processing, corroborating the study by Tallal,16 which found a correlation between reading and auditory temporal processing. This author found poor performance on temporal tests performed by the group with reading and writing disorder.

Murphy and Schochat17 also conducted a study analyzing the correlation between reading, phonological awareness, and auditory temporal processing in Brazilian children with dyslexia and reported that the group of children with dyslexia showed poor performance on the temporal auditory processing test, although they could not establish an association between this finding and poor performance on the test involving reading or phonological awareness tasks. Other studies15,18 have also found a relationship between abnormal results on tests assessing (central) auditory processing and difficulties in reading and writing tasks. Sauer et al.19 also found abnormal results on tests assessing CAPD in individuals with dyslexia when compared with individuals with typical development. In this study, the authors found that individuals with dyslexia showed statistically significant difference compared with the group of children with typical development on 
all tests assessing CAPD. Ingelghem et al.20 studied temporal processing in individuals with dyslexia and typical development and investigated the relationship between these variables. The researchers concluded that the results of the temporal processing assessment were statistically significant when related to reading skill. Significant differences were found when comparing the results of the temporal assessment of individuals with typical development and those with dyslexia. The group with dyslexia showed the highest rate of impairment on the temporal assessment compared with the other auditory skills assessed, which is in agreement with the findings by Heiervang et al.21

\section{Conclusion}

The analysis of our findings demonstrated that the individuals allocated to the CAPD group had worse results on the speech-in-noise and dichotic digit tests than those included in the dyslexic group. Furthermore, the frequency pattern test showed the same likelihood of abnormal results in the dyslexia and CAPD groups, which may indicate a correlation between temporal processing abilities and reading and writing skills.

\section{References}

1. World Health Organization. ICD-10: the international classification of diseases. Geneva: World Health Organization; 1993.

2. Welsh L, Welsh J, Cooper B. Cortical, subcortical and brainstem dysfunction: correlation in dyslexic children. Ann Otol Rhino Laryngol. 1982;91:310-15.

3. Banai K, Ahissar M. Auditory processing deficits in dyslexia: task or stimulus related? Cereb Cortex. 2006;16(12):1718-28.

4. Habib M. The neurological basis of developmental dyslexia. An overview and working hypothesis. Brain. 2000;123:2373-99.

5. Fitch RH, Miller S, Tallal P. Neurobiology of speech perception. Annu Rev Neurosci. 1997;20:331-53.

6. Van Ingelghem $\mathrm{M}$, van Wieringen A, Wouters J, Vandenbussche E, Onghena P, Ghesquiere P. Psychophysical evidence for a general temporal processing deficit in children with dyslexia. Neuroreport. 2001;12:3603-7.

7. Russo ICP. Acústica e Psicoacústica aplicadas à Fonoaudiologia. São Paulo: Lovise; 1999: cap. 16.

8. American National Standards Institute (ANSI). Specification for instruments to measure aural acoustic impedance and admittance (S3.6). New York: ANSI; 1989.

9. American National Standards Institute. Specification for instruments to measure aural acoustic impedance and admittance. New York: ANSI; 1987.

10. Pereira LD, Schochat E. Processamento auditivo central: manual de avaliação. São Paulo: Lovise; 1997. p.99-138.

11. Musiek FE. Frequency (pitch) and duration patterns tests. J Am Acad Audiol. 1994;5:265-8.
12. Pereira LD, Santos MFC. Escuta com dígitos. In: Processamento auditivo central: manual de avaliação. São Paulo: Lovise; 1997. p.147-50.

13. Bussab WO, Morettin PA. Estatística básica. 5a ed. São Paulo: Ed. Saraiva; 2002.

14. Katz J, Ivey RG. Tratado de audiologia clínica. São Paulo: Manole; 1999.

15. Talcott JB, Witton C, McLean MF, Hansen PC, Rees A, Green GGR, Stein JF. Dynamic sensory sensitivity and children's word decoding skills. Proc Natl Acad Sci USA. 2000;97:2952-7.

16. Tallal P. Auditory temporal perception, phonics and reading disabilities in children. Brain Lang. 1980;9:18298.

17. Murphy CFB, Schochat E. Correlações entre leitura, consciência fonológica e processamento temporal auditivo. Pró-Fono R Atual Cient. 2009;21(1):13-8.

18. Share D, Jorm AF, MacLean R, Matthews R. Temporal processing and reading disabilities. Reading Writing: Interdisciplinary J. 2002;15:151-78.

19. Sauer LO, Pereira LD, Ciasca SM, Pestun M, Guerreiro MM. Processamento auditivo e SPECT em crianças com dislexia. Arq Neuropsiquiatr. 2006;64(1):108-11.

20. Ingelghem MV, Wieringen A, Wouters J, Vendenbussche E, Onghena P, Ghesquiere P. Psychophysical evidence for a general temporal processing deficit in children with dyslexia. Cogn Neurosci Neuropsychol. 2001;12:3603-6.

21. Heiervang E, Stevenson J, Hugdahl K. Auditory processing in children with dyslexia. J Child Psychol Psychiatry. 2002;43:931-8. 